\title{
Study on Inheritance Gene of Ecological Civilization in Ancient Water Control Works of Zhejiang Province
}

\author{
Ye Zhou \\ Department of Civil Engineering, School of Marine Engineering Equipments, Zhejiang Ocean University, Zhoushan, China \\ Email address: \\ 3043109291@qq.com.cn \\ To cite this article: \\ Ye Zhou. Study on Inheritance Gene of Ecological Civilization in Ancient Water Control Works of Zhejiang Province. American Journal of \\ Water Science and Engineering. Vol. 6, No. 4, 2020, pp. 112-120. doi: 10.11648/j.ajwse.20200604.12
}

Received: November 21, 2020; Accepted: December 8, 2020; Published: December 16, 2020

\begin{abstract}
It is very difficult to directly judge whether a new water conservancy project meets the requirements of ecological civilization. Based on the knowledge of engineering, archaeology, economics and history, this paper studies the ancient water control engineering by means of comparative analysis, literature review, field investigation, case study, simulation restoration and model demonstration. This paper explores the inheritance genes of water ecological civilization from three dimensions: water philosophy, engineering technology and institutional arrangements. It holds that network flow is the gene of water ecological civilization inherited by ancient water control works in China. Network flow - a flow of resources, economy, culture and value - realizes, to a great degree, the water control goals of physical grooming, economic equilibrium and ecological prudence. From the perspective of water philosophy, it displays a traditional philosophy which is systematic, prudent and dialectical. In terms of engineering technology, network flow uses astronomical-geographic information complex system to plan water sources, design structures to utilize hydro energy, regulate water quality, protect aquatic organisms, so as to form a natural-artificial water system network. In view of institutional arrangements, it constructs a hierarchical system at national, local and private levels, integrating the water conservancy practices of ancient Chinese and the essence of the traditional culture and ideology.
\end{abstract}

Keywords: Ancients, Water Control Words, Ecological Civilization, Gene

\section{Introduction}

It is very difficult to judge directly whether a new water project meets the requirements of ecological civilization. A new attempt is made to judge the ecological nature of modern water projects by using the genes of water ecological civilization inherited from ancient water control practice and theory. Zhejiang Province is rich in water cultural heritage, from Liangzhu Dam, Hemudu Wooden Well to Beijing-Hangzhou Grand Canal, Tongji Weir. Many water control practices are flashing the wisdom of the ancients, providing a lot of valuable information for the study.

Some study on ancient water control ecological civilization in China focus on case studies, such as Jia Pu's study on the ruins of Luoyang Chengyang Canal excavated in Han and Wei dynasties [1], Fu Fan's on Fengshui of Beijing [2], Chen Liu's on the water system of Chenzhou Ancient City [3]. Some angle towards water philosophy. For instance, Tian Yingiie studies the ancient ecological culture and wisdom from the perspective of Yi-ology [4]; Lu Yong discussed the traditional philosophical idea of ancient water control [5]; Zhang Jiacheng holds that the Cosmos-Earth-Man System and Yin-Yang theory run through all scientific and practical activities in ancient China [6]. Some research place emphasis on engineering technology. Wu Shiyong studies the historical logic of the national canal network system formed through the communication between artificial canals and natural waterways [7]; Qiu Zhirong studies the relationship between the upper and lower dams, and Liangzhu Ancient City [8]; Zhou Bingqi thinks that ancient water control workds can be classified into four categories: flood control embankments, shipping canals, irrigation structures, and weir-dam-reservoir [9]; Zhang Yan thinks that the effective hydraulic technology and the application of hydrodynamics have contributed to those long-lasting ancient Chinese water control works [10]; 
Fu Fan [11], Han Shuangyu [10] and Lin Wenqi [12] discover the law balancing ancient urban construction and ecological civilization. Some researchers pay more attention to institutional arrangement. For example, Yuan Lin studies regional collaboration in ecological infrastructure construction [13]; Tu Shipping looks at the worship of Water God in Ningbo, Zhejiang [14]. Most of these studies focus on a particular aspect. Although some achievements have been made, there lacks systematic synthesis. This paper, in view of the inheritance gene of water ecological civilization, probes into the water philosophy, engineering technology and institutional arrangement in ancient water control works of long duration.

\section{Research Results}

\subsection{Research Objects}

There are many ancient water works and sites in Zhejiang Province, some of which last hundreds or even thousands of years and still benefit the local people. Twelve ancient water control works, were selected as the research objects, as shown in Table 1, through which the genes of water ecological civilization inheritance in China were revealed. These works, including Jianhu Lake in Shaoxing, can be divided into two categories: those in the plain river network, represented by Liangzhu ancient city and ancient Jianhu water system; those in the mountain river network, represented by Tongji Weir and Daliu Weir.

Table 1. Beginning Years and Water System of Selected Ancient Water Control Works.

\begin{tabular}{|c|c|c|c|c|}
\hline Name & Location & Beginning Construction Year & Major Structures & Water System \\
\hline Jianhu Lake & $\begin{array}{l}\text { Yucheng District, } \\
\text { Shaoxing }\end{array}$ & $\begin{array}{l}\text { Fifth year during the reign of } \\
\text { Emperor Shun, Han Dynasty }\end{array}$ & $\begin{array}{l}\text { canal, embankment, canal offlet, } \\
\text { gate }\end{array}$ & Shaoxin river network \\
\hline $\begin{array}{l}\text { Grand Canal } \\
\text { (Hangzhou section) }\end{array}$ & $\begin{array}{l}\text { Downtown of } \\
\text { Hangzhou }\end{array}$ & Sui, Tang and Song Dynasties & $\begin{array}{l}\text { West Lake, Tiaoxi River, } \\
\text { Beijing-Hangzhou Grand Canal }\end{array}$ & $\begin{array}{l}\text { Hangzhou urban water } \\
\text { system }\end{array}$ \\
\hline Daliu Weir & $\begin{array}{l}\text { Liucheng Town, Wuyi } \\
\text { County }\end{array}$ & Wanli reign of Ming Dynasty & cofferdam, gate, trench, structures & $\begin{array}{l}\text { Xuanping urban water } \\
\text { system }\end{array}$ \\
\hline Tongji Weir & Liandu District, Lishui & $\begin{array}{l}\text { Fourth year during the reign of } \\
\text { Tianjian of Liang, the Southern } \\
\text { Dynasties }\end{array}$ & cofferdam, gate, trench, cave & Bihu plain water system \\
\hline Haoxi Weir & Liandu District, Lishui & $\begin{array}{l}\text { Ninth year during the reign of } \\
\text { Xuanzong, Tang Dynasty }\end{array}$ & $\begin{array}{l}\text { cofferdam, water diversion gate, } \\
\text { trench }\end{array}$ & $\begin{array}{l}\text { Lishui Urban water } \\
\text { system }\end{array}$ \\
\hline Tuoshan Weir & $\begin{array}{l}\text { Haishu District, } \\
\text { Ningbo }\end{array}$ & $\begin{array}{l}\text { Seventh year during the reign of } \\
\text { Taihe, Tang Dynasty }\end{array}$ & $\begin{array}{l}\text { cofferdam, stone embankment, } \\
\text { water gate }\end{array}$ & $\begin{array}{l}\text { Ningbo Yinxi water } \\
\text { system }\end{array}$ \\
\hline $\begin{array}{l}\text { Liangzhu Ancient } \\
\text { Dam }\end{array}$ & $\begin{array}{l}\text { Yuhang District, } \\
\text { Hangzhou }\end{array}$ & $2000 \mathrm{BC}$ & reservoir, canal system & $\begin{array}{l}\text { Liangzhu Ancient City } \\
\text { water system }\end{array}$ \\
\hline Kuankou weir group & $\begin{array}{l}\text { Songyang County, } \\
\text { Lishui }\end{array}$ & Ming Dynasty & $\begin{array}{l}6 \text { weirs, water diversion gate, } \\
\text { trench, etc. }\end{array}$ & $\begin{array}{l}\text { Songgu plain water } \\
\text { system }\end{array}$ \\
\hline Guangji weir group & Jinyun County, Lishui & $\begin{array}{l}\text { Song Dynasty } \\
\text { Ming Dynasty }\end{array}$ & 4 weirs, trench, water intake, etc. & $\begin{array}{l}\text { Huzheng plain water } \\
\text { system }\end{array}$ \\
\hline Jiuqu Ditch & Shengzhou, Shaoxing & Wanli reign of Ming Dynasty & $\begin{array}{l}\text { cofferdam, water diversion gate, } \\
\text { ditch }\end{array}$ & $\begin{array}{l}\text { Huatangcun water } \\
\text { system }\end{array}$ \\
\hline Wudu Weir & $\begin{array}{l}\text { Qingyuan County, } \\
\text { Lishui }\end{array}$ & $\begin{array}{l}\text { Eighteen year during he reign of } \\
\text { Hongwu, Ming Dysnaty (1385) }\end{array}$ & Weir, water intakes, trench & Wudu irrigation system \\
\hline $\begin{array}{l}\text { Jiangxi Weir, Yunshui } \\
\text { Channel }\end{array}$ & Longquan City, Lishui & $\begin{array}{l}\text { First year during the reign of } \\
\text { Jinkang, Song Dynasty (1126) }\end{array}$ & Weir, gate, branch channel & $\begin{array}{l}\text { Longquan urban water } \\
\text { system }\end{array}$ \\
\hline
\end{tabular}

Note:

a) Guankou weir group consists of 6 weirs, respectively Xiangshi Weir, Guankou Weir, JinliangWeir, Wuyang Weir, Qinglong Weir, and Bailong Weir, among which Jinliang Weir is of runoff type.

b) Guangji weir dam consists of 4 weirs: Guangji Weir, Dongliang Weir, Jinsi Weir, and Qingning Weir.

c) Tongji weir group comprises Tongji Weir and Jingou Weir.

\subsection{Methodology}

By means of comparative analysis, literature review, field investigation, case study, simulation restoration and model demonstration, the ancient water control works were studied based on comprehensive knowledge of engineering, archaeology, economics, history, etc. Ancient literature on water conservancy, mountains and rivers was referred to, and the related heritage, cultural relics and monographs inside and outside the province were examined, particularly including local chronicles of counties and cities, chronicles of water resources, and steles, monographs, articles and biographies about rivers and lakes. Major historical events, water control activities and allusions of important water control works were combed.

GIS software was applied to simulate the geographic information and hydrodynamic value of those ancient water control works. Analysis was also made on the technical characteristics and water control effect of them. The hydrodynamic factors of flow state, velocity, flow and water level of river network were calculated and compared by the two-dimensional hydrodynamic mathematical model. Also, the hydrological relationship and characteristics in ancient and modern engineering inheritance were analyzed. The hydrodynamic modeling theory of river network includes the basic equation of flow motion and the condition of definite 
solution.

Basic equation of flow motion is given below:

$$
\frac{\partial h}{\partial t}+\frac{\partial u h}{\partial x}+\frac{\partial u h}{\partial y}=0
$$

Flow motion equation:

$$
\begin{aligned}
& \frac{\partial u}{\partial t}+u \frac{\partial u}{\partial x}+v \frac{\partial u}{\partial y}+g \frac{n^{2} u \sqrt{u^{2}+v^{2}}}{h^{4 / 3}}-v_{t}\left(\frac{\partial^{2} u}{\partial x^{2}}+\frac{\partial^{2} u}{\partial y^{2}}\right)=0 \\
& \frac{\partial v}{\partial t}+u \frac{\partial v}{\partial x}+v \frac{\partial v}{\partial y}+g \frac{n^{2} v \sqrt{u^{2}+v^{2}}}{h^{4 / 3}}-v_{t}\left(\frac{\partial^{2} v}{\partial x^{2}}+\frac{\partial^{2} v}{\partial y^{2}}\right)=0
\end{aligned}
$$

In it, $h$ is water depth; $u$ and $v$ respectively refer to transverse and longitudinal flow velocity; $Z$ is water level; $n$ is Manning roughness; $V t$ is eddy current coefficient. Definite solution condition includes initial condition and boundary condition. The initial value is set as a constant, and the initial condition has no effect on the final result. In this model, three different boundary conditions are used: land condition (zero vertical velocity, zero velocity), velocity boundary condition, flux boundary condition, water level boundary condition, discharge boundary condition, etc

\subsection{Results: Network Flow Is the Gene of Ecological Civilization Inherited from Ancient Water Control Works}

The research team conducted a systematic investigation of the 12 selected works, combing and giving textual research on the cultural relics collected in the relevant museums and the heritage displayed on the vast land or written in ancient books.
Three elements of network flow were identified from the research paradigm of water ecological civilization in historical dimension (2019). The efficiency of network collocation was studied from networking and joint scheduling of the reservoirs in Yuanshui, Ningbo and Yangxi reservoir group in Yongkang (2016). The long duration of network flow management and the thought of man-nature unity in water control featured by the water system of Jianhu Lake in Shaoxing were discovered (2019). The role of hydrodynamics in the inheritance of ancient ecological civilization was recognized from the study of Daliu Weir water system. Understanding of the technical characteristics and requirements of fishways was also obtained in the study of the fishway of Cao'e River sluice (2017). The above research clearly shows that network flow is the gene of ecological civilization inheritance of river control in China, as both the plain river network system and mountain river network system share common characteristics and research conclusions. From ancient times to modern times, the network flow composed of natural and artificial river channels has been formed through the continuous efforts on constructing river channels and improving the network.

Network flow contains the connotation of politics, economy, culture, resources and so on. In form, it is the physical network of rivers, natural or artificial. Actually, it is the organic fusion and external embodiment of thought, technology and institution, where geographic information, natural hydro energy and seasonal changes are utilized to develop and exploit water resources in light of the situation and adapting to local conditions. What network flow conveys is not only water but also human civilization. This gene research approach is shown in Figure 1.

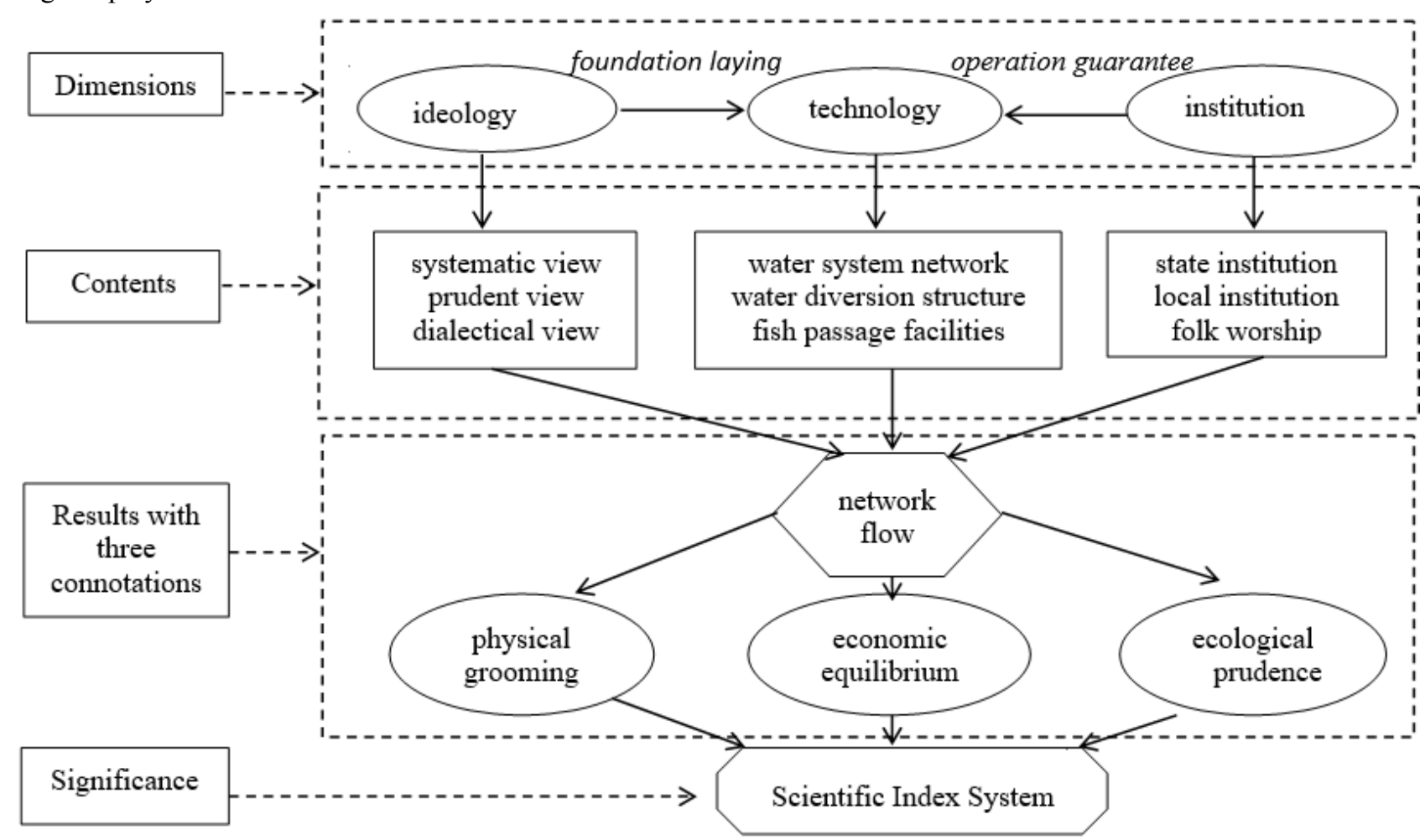

Figure 1. Research Map of Inherence Genetic Core. 
Modern science and technology are used to study the three elements of network flow: water philosophy, engineering technology, and institutional arrangement. The main objectives of water control are to ultimately facilitate economic development and social harmony by grooming

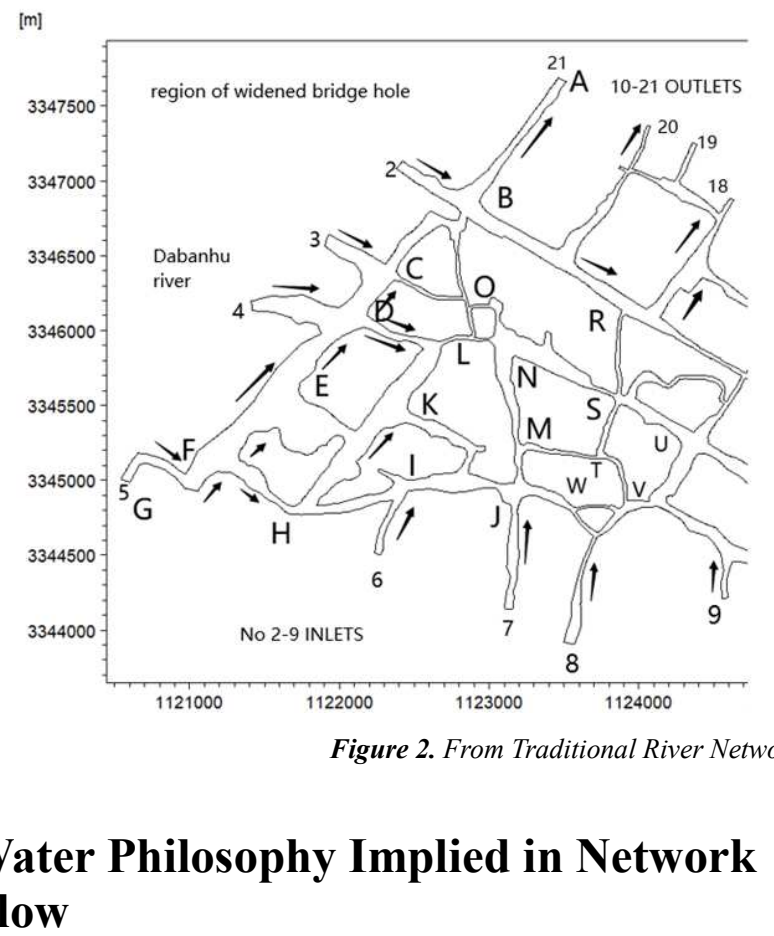

Water control practices of ancient Chinese were deeply influenced by the traditional philosophy, aiming at rationally transforming the natural river system for human use through the ways of astronomy, geography and introspection. Specifically, practices like water system planning, engineering construction, water intake and use, were guided by the ideas of making the best use of situations, adapting measures to local conditions, and harmonizing human being and nature, so as to achieve the goals of physical grooming, economic equilibrium, and ecological prudence.

\subsection{Heaven-Earth-Man System Cosmic Outlook}

One idea about the traditional Chinese water philosophy is the systematic harmony between human being and nature [15], which comes from Zhouyi, the Book of Changes, holding that human society is a whole with nature, and it is a part of nature, not the opposite of nature. This idea is mainly embodied in the San Cai theory (triple treasures), where the six lines are arranged in pairs, reflecting three levels. The forefathers thought that the first and second signs earth, the third and fourth signs man, while the fifth and sixth signs heaven. Hence, by simplifying the things in the universe into three talents, heaven, earth and man, or called triple treasures, the entire cosmos is constituted. Heaven and earth refer to nature, and man refers to human society. Nature and human society are also the objects to be recognized by human beings. Human beings are not only the object of cognition, but also the subject water resources physically, achieving balance economically, and being prudent ecologically. It is found that from ancient times to modern times, although the method and technology of water control have changed, the core of network flow inheritance has not changed. See Figure 2 below.

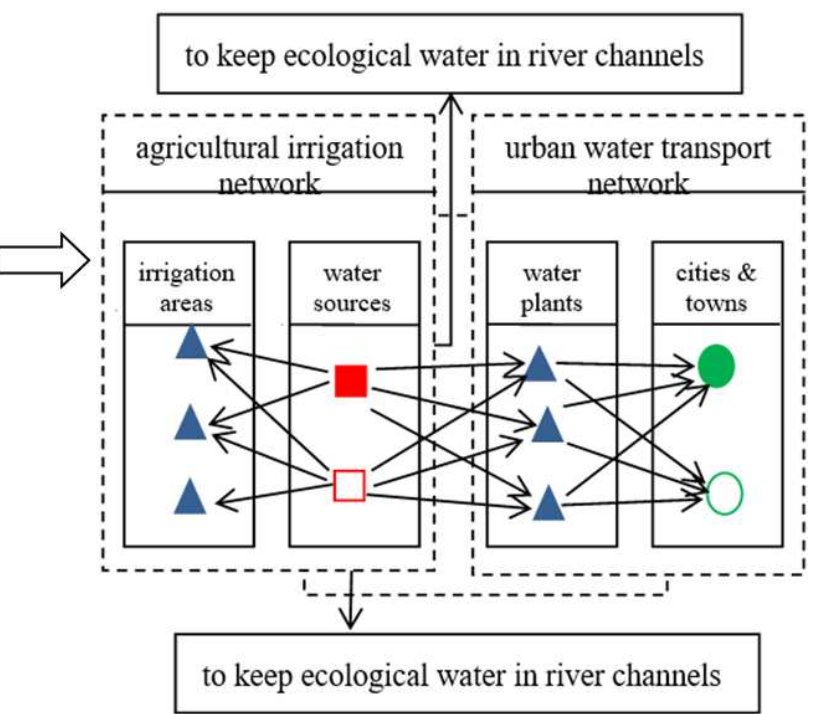

of cognition. They take the human society itself as the research object, examining its movement law by associating it with the nature. The systematic thought of man and nature union was embodied in the planning of water system where human needs were satisfied at the minimum cost by integrating natural rivers with human needs for water resources, arranging towns, villages and engineering facilities according to local conditions and situations. The Heaven-Earth-Man system emphasizes the significance of systematic and comprehensive information. The ancients observed astronomical phenomena, inspected geographic features, and reflecting introspectively, and their water control ideas and unique ways of thinking were typically displayed in Xuanping ancient city and the urban water system of Lishui $[15,16]$.

\subsection{Prudence in Utilizing Natural Resources}

Our traditional philosophy believes that human beings must adopt a temperance attitude. This restraint is reflected not only in the demand for resources from nature, but also in the attitude towards human life. Prudence in traditional philosophy was elaborated not only in Zhouyi but also in Confucianism, Buddhism and Taoism. It was also recorded in the water control practices, like solar terms, regulating sluices, water saving, etc. Prudence means in three ways: one is to neutralize; the second is to stop when you should stop and act when you should act, accelerating or slowing down with controlled rhythm; the third is to renovate on daily basis, as everything has life and needs to be updated all the time. The existence and activity of living beings depend on non-biological 
objective conditions, an ecosystem is therefore formed by integrating biological and environmental systems in a certain space. This ecosystem is always in motion, as depicted in Interpretation of Zhouyi, the Book of Changes, that "continuous creation of life is change". That is to say, after the formation of life, generation after generation of reproduction and development breed in an endless succession. In the ecosystem, each part is connected and restricted to each other, so as to achieve ecological balance. Once the ecosystem is broken, means are exhausted. The other parts of the ecosystem, nevertheless, can play a coordinating role. "When all means are exhausted, changes become necessary". Ecological self-coordination or artificial coordination can turn things around, that is, "once changed, a solution emerges". The circulation of matter and the transformation of energy will again achieve an appropriate new ecological equilibrium state, which will lead to a period of relative stability. That is, "solutions to problems will result in sustainability". Living beings exchange substance and carry out energy transformation with the environment through assimilation and alienation, so as to realize alternate renewal. During the development and utilization of water resources in ancient times, the idea of prudence could be seen everywhere, especially in the process of network flow formation in this study [14].

\subsection{Dialectical View on the Practices of Water Control}

Chinese Yin-Yang \& Wu-Xing theory ( Wu-Xing means five elements, including metal, wood, water, fire and earth) specificly reflects the dialectical thought. Yin and Yang not only point out the two sides of contradiction and opposition, but also specify the main characteristics of both sides. The mutual aid and transformation between Yin and Yang sum up the evolution law of things. In the ancient water control practices, great attentions have been paid to adapting to major environmental conditions, organizing and altering minor environmental conditions. To adapt to major environmental conditions that human beings can not change, such as climate and meteorological conditions, people seek advantages and avoid harm by selecting appropriate sites for cities to avoid environmental factors that threaten human beings, such as adverse engineering geological and hydrogeological conditions, floods, strong winds and so on. However, on the basis of conforming to the natural process and not violating the ecological cycle, the environmental conditions on the small scale around the city have been effectively dredged, reformed and utilized to create comfortable and safe living conditions. All these thoughts are embodied in the water systems under study [15], and the two sides of the contradiction are transformed to each other through dialectical thinking.

\section{Engineering Technology Contained in Network Flow}

The study on ancient water control works and water systems shows that the ancients have used astronomical-geographic information and hydrodynamics to build networks by grooming, combining and compounding water systems to to meet human beings' needs of for more water resources for water supply, irrigation, fire fighting, ecology, leisure, landscape and so on. From the water control in ancient Zhejiang Province, many innovative practices can be seen in water conservancy engineering technology from time to time in China.

\subsection{Selecting Water Sources}

"How can it be so clear and cool? For water fresh comes from its source." One of the key points of ancient water system management was to select appropriate water sources to ensures water quantity and quality as well. The utilization of ancient water system was closely related to the planning of towns and villages. The relationship between geographic and climatic factors and human well being was considered in the water control works. Water enabled the origin of towns and villages, and in turn, the development of towns and villages promoted the development and perfection of water systems. Common features that ancient towns and villages mostly considered in planning their water system are the following. The country, located in the monsoon climate area, the northern hemisphere temperate zone, is cold in winter with strong northwest wind prevailing, though the mountains in the north can block the cold winter wind. It is hot summer in summer with the prevailing southeast wind, and the water gaps in the southeast can make the southeast wind blowing to the site and therefore increase air humidity. Towns and villages in the sunny slope of the mountain enjoy adequate sunshine and easy access to water as they are close to rivers. In planning villages and towns, the terrain low in southeast and high in northwest is generally chosen. As the south bank of a river is usually seriously eroded, the site selected on the north bank is not affected by flood. Water sources are chosen high up in the northwest mountains, so that the water can be kept clean.

This kind of urban planning thought was very clearly displayed in the layout of Liangzhu ancient city, Hangzhou in Sui and Tang dynasties, Xuanping ancient city and so on. For example, in Lianzhu ancient city, a total of 11 embankments constituted a river network system, and a reservoir with a storage capacity of 2.75 million cubic meters was formed in the northwest of the city [8]. So did the ancient city Hangzhou during Sui and Tang dynasties. Xuanping ancient city was more typical, as Daliu Weir in its northwest diverted the water source to Lvtan Weir in the southeast. Figure 3 is the diagram of water system of Xuanping ancient city.

\subsection{Composite Natural-artificial Water Network}

A very prominent feature of network flow formation is its long duration. After hundreds or even thousands of years of construction, many works have finally formed a complex and perfect natural-artificial water system network, which often naturally accommodates many "schools"-water systems. For instance, Tuoshan Weir, together with the outer river, the 
inland river, Sun Lake, Moon Lake, formed the water network of ancient Ningbo city; Daliu Weir, together with Dongxi Stream, Xixi Stream, and inner channel system, formed the water network of Xuanping ancient city; the water system of Chuzhou ancient city was established by Daxi Stream of Oujiang River and its branches, Tongji Weir channel system, Haoxiyan River, and Liyang Channel. The change from natural river network, natural-artificial river network, to natural-artificial river network with reservoir regulation and storage, illustrated that networking is becoming more and more complex, and the utilization rate of water resources is becoming higher and higher.

Water system network is composed of water sources, links, nodes, water tools and so on. The water sources are mainly northwest wind water sources N. river channels, springs or wells; the links include river channels, trenches, pipeline; the nodes are reservoirs, river embankments, lakes, gates, stone cases and so on; water tools refer to those devices used to collect, transport, store and drink water. According to the simulation and calculation of water system network by two-dimensional hydrodynamic model [17, 18], the most prominent characteristics of network include: first, network can realize resource sharing, improve water resources utilization ratio, and reduce water disaster; second, it can transmit and exchange information quickly between nodes; third, it has high reliability, that is, when one part of the network has problems, the other parts can automatically take over; forth, it is easy to distribute, so that water resources can enable more land development (for agricultural society).
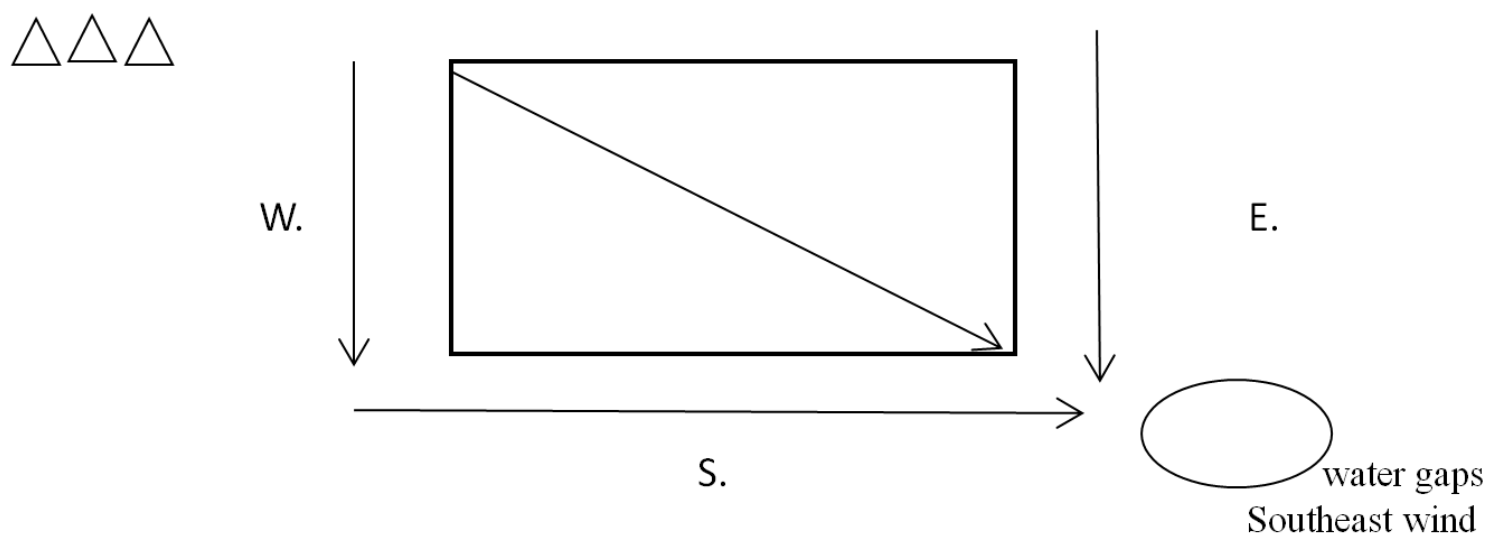

Figure 3. Diagram of Common Water System Layout for Towns and Villages.

\subsection{Utilization of Hydropower in Ancient Times}

In ancient water control works in China, geographical information and hydropower have been skillfully used, and the latter is also the most economical power. Because there was no electric power at that time, people relied only on natural water energy as power to distribute water resources for various purposes. A large number of works using hydroenergy were designed to make the river network flow automatically.

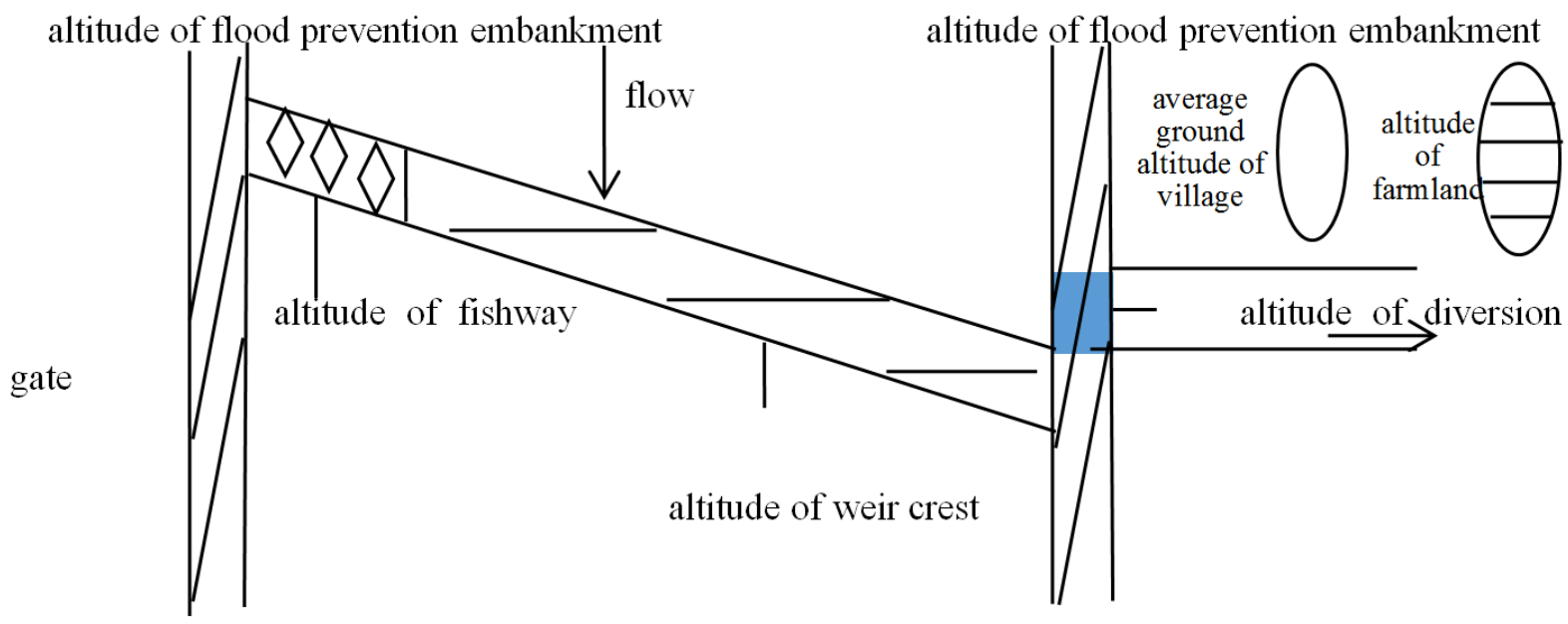

Figure 4. Diagram of Altitude System of Gate, Weir, Embankment, Farmland and Village.
A complete altitude system, fueled by hydroenergy, was formed to divert water from sluices (or water sources) to villages and towns, and finally to farmland and tail channels. Even at the same diversion gate, weir, flood prevention embankment, diversion sluice, fishway were of different altitude for water distribution. Figure 4 is a schematic diagram of the altitude system. Table 2 shows five examples of it. altitude of farmland

altitude of flood prevention embankment 
Table 2. List of Altitudes of Some Flow Networks Unit:m.

\begin{tabular}{lllllll}
\hline Name & $\begin{array}{l}\text { Altitude } \\
\text { of Weir } \\
\text { Crest }\end{array}$ & $\begin{array}{l}\text { Altitude of } \\
\text { Water Intake } \\
\text { (width) }\end{array}$ & $\begin{array}{l}\text { Altitude of } \\
\text { Embankment } \\
\text { Crest }\end{array}$ & Altitude of Fishway Top & Other Altitudes & $\begin{array}{l}\text { Altitude Range } \\
\text { of farmland } \\
\text { irrigated }\end{array}$ \\
\hline Jiuqu Ditch & 94.63 & $94.31(0.97)$ & 97.22 & originally of unity slope & Time tower: 95.59 & $82.59-93.59$ \\
Wudu Weir & 332.47 & $331.30(1.00)$ & 333.89 & unity slope (1:20) & Angle between flow and weir: $30^{\circ}$ & $313.0-327.0$ \\
Wanshouao Weir & 302.31 & $301.71(2.00)$ & 304.39 & originally of unity slope & Headwork overflow: 303.39 & $292.1-302.7$ \\
Zhiao Weir & 217.98 & $216.98(1.38)$ & 219.22 & originally of unity slope & Tailwater: 215.98 & $187.4-214.0$ \\
YunshuiChannel & 206.12 & $205.21(0.80)$ & 206.68 & 205.82 (groove shaped fishway) & Outlet: 205.88 & $192.2-199.7$ \\
\hline
\end{tabular}

Note: For weirs of unity slope type, the altitudes of fishway top and weir crest are the same. The five irrigation areas in the table cover respectively $1100 \mathrm{mu}$, $3396 \mathrm{mu}, 1400 \mathrm{mu}, 3700 \mathrm{mu}$, and $3300 \mathrm{mu}$ ( $\mathrm{mu}$, a unit of area, equals 0.0667 hectares).

\subsection{Engineering Structures for Managing Water Quality}

A river network contains many kinds of structures to manage and control water quality, including salinity, sediment, sundries and so on. Among the selected 12 water control works, most are ancient weirs of different functions, including overflow dam, retaining weir, diversion weir, and flood diversion weir. According to different masonry materials, these weirs can be divided into rockfill weir, crib rockfill weir, block stone barrier weir, wooden earth gravel weir, and boulder barrier weir. Jinliang Weir is on the other hand of run-off type. Due to different diversion purposes, the proportion of water diversion varies greatly. Water flow and its rate are controlled through different altitude and width of gates. Table 3 introduces the dimensions of some ancient weirs. Control gates of plain river network play the role of distributing water, while Gaizha gates (gates for general uses) of mountain water system functions very similarly. Two-dimensional hydrodynamic model was used to simulate and calculate water flow and its proportion [16]. It was seen that water diverted from natural rivers took up $10 \%-30 \%$ of the total river flow, reaching a maximum of $40 \%$ for rivers of comprehensive utilization during dry seasons.

Table 3. Dimensions of Some Weir Works Unit:m.

\begin{tabular}{|c|c|c|c|c|c|c|c|c|c|c|c|}
\hline Works & Height & Length & Width & Works & Height & Length & Width & Works & Height & Length & Width \\
\hline $\begin{array}{l}\text { Daliu Weir, } \\
\text { Wuyi }\end{array}$ & 2.0 & 50 & 12.0 & Haoxi Weir, Liandu & 4.0 & 225 & 27 & $\begin{array}{l}\text { Jingou Weir, } \\
\text { Liandu }\end{array}$ & 3.3 & 85 & 10.1 \\
\hline $\begin{array}{l}\text { Tuoshan } \\
\text { Weir, Yinzhou }\end{array}$ & 5.0 & 113.7 & $3.2 / 4.8$ & $\begin{array}{l}\text { Qiuqu Ditch, } \\
\text { Shengzhou }\end{array}$ & 1.6 & 42 & 16 & Guangji Weir & $1.4-1.5$ & 149 & $\begin{array}{l}\text { About } \\
10\end{array}$ \\
\hline $\begin{array}{l}\text { Wanshouao, } \\
\text { Longquan }\end{array}$ & 2.5 & 120 & 8.0 & $\begin{array}{l}\text { Wudu Weir, } \\
\text { Qingyuan }\end{array}$ & 3.2 & 167 & 29 & Zhiao Weir & 2.5 & 62.5 & 6.0 \\
\hline $\begin{array}{l}\text { Tongji Weir, } \\
\text { Liandu }\end{array}$ & 2.5 & 275 & 25 & $\begin{array}{l}\text { Lvfeng Weir, } \\
\text { Liandu }\end{array}$ & 3.4 & 360 & 35 & $\begin{array}{l}\text { Guankou } \\
\text { Weir }\end{array}$ & 1.5 & 135 & 14 \\
\hline
\end{tabular}

Note: As many weirs have been rehabilitated and therefore changed greatly in structure compared with the original ones, especially the width of the weir crest. That is why only the bottom width is listed here.

\subsection{Ecological Protection Function of Weirs}

Hydrodynamic model was used to simulate water flow so as to study the impacts of ancient water control on aquatic organisms such as fish. The most typical impact was of the weirs in mountain area on fish migration. The construction of weirs changed the permeability of river channel, and its flow state and hydrological characteristics. In the dry season every year, water reduced river reaches, caused by the slowing water flow velocity, shrunk aquatic living space. Consequently, the number and population of aquatic algae, plankton and benthic animals would change to a certain extent, and the fish adapted to the flowing environment would also decrease in population. Statistics disclosed by Zhejiang Aquatic Resources Survey1 in 1970s showed that many freshwater fish species, especially in Oujiang, Zhejiang Province, were the same as those in Taiwan Province. To some extent, this implied that the weirs built in ancient times produced small impact on fish population and quantity.

1 Zhejiang Freshwater Aquatic Research Institute. Preliminary Investigation Report of Oujiang Aquatic Resources, March 1973.
In order to reduce the influence on fish migration and optimize the engineering structure to adapt the fish to the new living environment, weirs have been designed to facilitate the upstream and downstream swimming of fish. In particular, multiple weirs were designed in mountain rivers to reduce their height. Examples were the six weirs in Songgu Plain and four weirs in Hupzhen Plain. There were also multi-layer weirs, which shaped like fish scale with each layer of height controlled in a certain range. For instance, Tuoshan Weir consists of three layers. Some weirs included a groove-shaped fishway in the middle of their crest, like the one of Jiangxi Weir. In its vertical direction with the river, Tongji Weir was serrated with concaves for fish to pass through. Due to the optimized structure design, most ancient weirs were not high, about 2-3 meters, and their downstream slopes were slow, usually 1:8-1:12, some even 1:20. See Table 2 and Table 3 for more details. Table 4 shows the flow capacity of common fish depicted in the Summary Report on Fishway Design of Cao'e River Sluice in Zhejiang Province, which was utilized to conduct simulation of ancient weirs. The calculation results showed that the living conditions for fish was basically unaffected with the fishway design displayed in Table 2 [19]. 
Table 4. Measured Value of Fish Capacity to Overcome Flow Velocity in Cao' e River Basin.

\begin{tabular}{llll}
\hline Fish & $\begin{array}{l}\text { Body length/width } \\
\text { (cm) }\end{array}$ & $\begin{array}{l}\text { Favorite } \\
\text { velocity }(\mathbf{m} / \mathbf{s})\end{array}$ & $\begin{array}{l}\text { Extreme } \\
\text { velocity }(\mathbf{m} / \mathbf{s})\end{array}$ \\
\hline eel fry & $5-10$ (length) & $0.18-0.25$ & $0.45-0.50$ \\
young crab & $1-3$ (width) & $0.18-0.23$ & $0.40-0.50$ \\
pike & $14-17$ (length) & $0.40-0.60$ & 0.80 \\
Coilia ectenes & $10-25$ (length) & $0.20-0.30$ & $0.40-050$ \\
\hline
\end{tabular}

Local administration in ancient time attached great importance to the investigation of fishery resources in the region. According to Local Chronicle of Wenzhou, records about Grouper, Ayufish, and carp in Oujiang River basin can be found during the reign of Hongwu and Wanli in Ming Dynasty. Written records on the twenty-fifth year during the reign of Qianlong in Qing Dynasty (1760) showed 45 species of fish, including anchovies, Rumble Fish, eel, bass, herring, squid, etc., with details on the growth, spawning, migration of some valuable economic fish. In Local Chronical of Chuzhou (now Lishui) compiled on the thirteenth year during the reign of Tongzhi in Qing Dynasty (1874), silver carp, bighead carp, grass carp, and shells were recorded.

\section{Institutional Arrangement Contained in Network Flow}

Institutional arrangement refers to "rules or rules of action that require common compliance". The institutional arrangement in ancient water control was constituted at three levels: national, local and private, formulating the institutional system of constructing and operating water control structures. The system emphasized such concepts as cooperative water control, incentive compatibility, imprudence, and big harmony, laying a legal and moral foundation for the construction of a harmonious society.

\subsection{Legal System at State Level}

Most of the regulations on water control in ancient China were mostly components of national laws and regulations. As early as the Spring and Autumn period, the state code of Chu had specific provisions on water conservancy. There were many proven practices in the codes that have been formed throughout the ages. For instance, in Interpretation of Zhouyi, "institutional restraint" was mentioned to encourage the whole society live life prudently. After the Qin and Han dynasties, special laws and regulations on water conservancy appeared, such as Shuiling (Regulation on Water) of Han Dynasty, Shuibushi (The Laws by the Water Conservancy Department) of Tang Dynasty, Nongtian Shuili Yuesu (Farmland and Water Conservancy Restriction) of Song Dynasty, and Hefangling (Regulation on River Potection) of Jin Dynasty, and so on. All theses were water control institution at state level, stipulating that water resources were public wealth, and no private monopoly was allowed. Shuibushi covered farmland and water conservancy management, hydraulic machinery setting and water consumption quota, management and maintenance of ship lock and bridge ferry, fishery management and urban waterway management. Another manifestation of the system at national level was on the ownership of the works. Some works were publicly owned, like Daliu Weir and Yunshui Channel; some were privately owned. Different nature of the works indicated different construction units. The administration always provided financial subsidies for those publicly owned works.

\subsection{Conventions of Grass-roots Organizations}

Grass-roots organizations include rural administrative institutions below the county level, including villagers' autonomous organizations. They enabled the integration of "artificial-natural system" and "regional (or rural) governance system". This system of grass-roots governance mainly coordinated the relationship between people, restricted individual water use behavior, and harmonized the water use among tribal groups. For instance, Huatang Village, where Jiuqu Ditch was located, drew up the Convention of Ditch. Xuanping County government developed provision on using water of Daliu Weir. On the fifth year of Qiantao reign in South Song dynasty, Fan Chengda, governor of Chuzhou (now Lishui) enacted twenty articles of Tongji Weir Code. On the fourth year of Daoguang reign in Qing dynasty, magistrate Lei Xuehai reintroduced eight articles of weir code. In general, the provisions of the local administration reflected three objectives. The first was to encourage people to moderate their water use without waste. The second was to coordinate water consumption in space and time to prevent conflicts of interest. The last was to establish water engineering management mechanism. For example, from the ninth year of Jiajing reign of Ming dynasty (1530) to the second year of Gaungxu reign of Qing dynasty (1876), there existed weir board for Fangxi Weir in Songyang County, with selected Weir Chief. The county established Haoxi Weir Board on the sixteenth year of Jiaqing reign of Qing dynasty (1811) and formed management mechanism for constructing, financing, administrating and land requisition works. [20]

\subsection{Folk Hero Worship}

The worship of water gods appeared all along the history of ancient water control, most typically embodied by Shaoxing Dayu Mausoleum and over 200 relics related to Yu the Great in Cao'e River basin. To memorize Wang Yuanwei who constructed Tuoshan Weir in Yingzhou, Ningbo, people built Tuoshan Yide Temple (Yide means legacy). People living in Xuanping River basin in Wuyi built Chenghuang Temple (Chenghuang means town god) dedicated to Hang Zonggang and Chen Yingling. In Cao'e River Basin, people worshiped Gou Jian, King of Yue, Ma Zhen, Tang Shaoen and other water heroes in addition to Dayu. Water God (Yangong) worship was also seen in Jaixing and Hangzhou, cities along the Grand Canal. People in Songyang built stone column hall to praise the achievements of Zhou Hanjie who constructed Bailong Weir, and Zhannan Ersima Temple to commemorate Zhan Sima and Nan Sims on their contributions on Tongji Weir. Some counties kept the records of water control activities in the form of water monument engraving, cliff stone carving. For example, in Songyang, there are 14 engraved tablets and 7 cliff inscriptions. The folk worship 
of water gods was actually the worship of water. In agricultural society, the ultimate goal of water control was to have favorable climatic weathers, and unruffled rivers and lakes.

\section{Conclusion}

It can be concluded that the genes of ecological civilization inherited from ancient water control works in China are embodied in network flow. Although modern water control has a completely different engineering and technical background from ancient times, the thought of water control and the goal of building ecological civilization are all time the same. Network flow is a resource flow, economic flow, cultural flow and value flow. It can be summarized in four points. First, water philosophy, engineering technology and institutional arrangement constitute its core. Second, the goals of network flow are physical grooming, economic equilibrium and ecological prudence so as to realize economic development and social harmony. Third, the selection of water sources and the utilization of hydro energy are the key elements to realize network flow. Fourth, a number of engineering structures with scientific design and exquisite workmanship are the basic guarantee for the realization of network flow. It is also found that many newly built weirs or recently rehabilitated ancient weirs have deviated from the original design ideas and had more impact on water ecological civilization.

\section{Funding}

The paper is one of the achievements of the Research on Optimal Allocation Mechanism and Model of Regional Water Resources with Coupled Incentive Compatibility (No. 51979249) supported by the National Natural Science Foundation of China (NSFC).

\section{References}

[1] Jia Pu. Ecological Water Conservancy Construction of Yangqu Site and Ancient Capital of Luoyang City in Han Dynasty [J]. Zhongzhou Journal, 2017 (7): 110-114.

[2] Fu Fan, Zhao Caijun. A Reflection on Feng Shui of Beijing in Dry Season [J]. Chinese Gardens, 2010 (05): 80-82.

[3] Chen Liu, Liang Rui. Construction of Small and Medium-sized Cities in Ancient China under Ecological Perspective-Taking Chenzhou in Qing Dynasty as Example [J]. Central China Architecture, 2016, 224 (01): 104-107.

[4] Tian Jieying. On Ecological Wisdom in Ancient China and Construction of Contemporary Ecological Civilization [J]. Journal of Changzhou University: Social Sciences Edition, 2013, (02): P. 5-9.

[5] Lu Yong, Hong Cheng. Traditional Philosophy and Its Application in Ancient Chinese Water Control [J]. Journal of China University of Agriculture and Forestry Science and Technology, 2014 (1): 132-137.

[6] Zhang Jiacheng. On the Scientific Thought of Water Control in Ancient China [J]. Progress in Water Science, 1996 (6): 158-161.
[7] Wu Shiyong. Historical Logic of Ancient Water Control, River Opening and Water Channel [J]. Journal of Shenzhen University: 2018 (2): 152-160.

[8] Qiu Zhirong, Zhang Weidong, Ru Jingwen. A Textual research and Study on Water Conservancy Works of Liangzhu Cultural Site [J] Journal of Zhejiang University of Water Resources and Electric Power, 2016 (3).

[9] Zhou Bingqi. Analysis on the Thought of Water Control in Ancient Water Projects [J]. Hydro Energy Economy, 2016 (4): $112-112,114$

[10] Zhang Yan. How can ancient Chinese water conservancy works last for thousands of years [J]. Encyclopedia Knowledge, 2018.03B: 2-9.

[11] Lin Wenqi. Ecological Thought and Enlightenment in Ancient Chinese Urban Construction [J] China Planner, 2002, 018 (005): 5-7.

[12] Yuan Lin. [J]. Regional Collaboration in Ecological Infrastructure Construction [J]. Urban planning, 2016 (8): $14-15$.

[13] Tu Shi Ping. A Study on the Worship Culture of Water God in Ningbo, Zhejiang Province [J]. Journal of North China University of Water Resources and Electric Power, 2016 (032): 001/14-18.

[14] Yang Wenheng. Book of changes and Ecological Environment [M], China Bookstore Press, first Edition, 2003.

[15] Ye Zhou. Historical Dimensions: Study on Ecological Civilization Gene of Water Diversion Project of Daliu Weir [J] Journal of Zhejiang University of Water Resources and Electric Power, 2020 (3): 9-15.

[16] Ye Zhou. A Study on the Efficiency of Regional Water Resources Allocation Based on Network Scheduling of reservoirs Group [J]. Small Hydropower, 2016, 000 (003): 1-4.

[17] Li Dongfeng, Ye Zhou. Study on Water Dynamics of Jianhu Water System [R]. Zhejiang University of Water Resources and Electric Power, 2014.

[18] Yin Hui, Ye Zhou. A Study on the Effect of Crossing Fish in Fishway of Cao'e River Sluice [R]. hejiang University of Water Resources and Electric Power, 2017.

[19] Liang Xiaohua. Ancient Weirs of Chuzhou [M]. Zhejiang Ancient Books Press, first edition, April 2013.

[20] Lishui Water Resources Bureau, etc. Water Rhyme-Water Cultural Heritage in Lishui City [M]. Xiling Printing Press, first edition, March 2020.

\section{Biography}

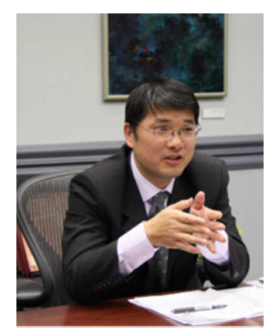

Ye Zhou, born in October 1964, $\mathrm{PhD}$, engineering professor, master supervisor, has long been specializing in hydropower resources and optimal water resources allocation. 